\title{
THE TURFS QUALITY OF SELECTED SLOVAK VARIETIES OF THE GENUS FESTUCA UNDER THE CONDITIONS WITHOUT IRRIGATION
}

\author{
P. Kovár, L'. Vozár, J. Jančovič
}

Received: September 12, 2012

\begin{abstract}
KOVÁR, P., VOZÁR, L., JANČOVIČ, J.: The turfs quality of selected Slovak varieties of the genus Festuca under the conditions without irrigation. Acta univ. agric. et silvic. Mendel. Brun., 2012, LX, No. 6, pp. 181-188

The development of botanical composition (in \% dominance) in the period 2005-2011 and growthproduction process in the years 2007-2011 were evaluated in small-plots experiment with selected Slovak varieties of species of the genus Festuca. The experiment was realized under the conditions without irrigation of south-western Slovakia (locality Nitra). The data of botanical composition of turfs showed that fescue varieties were able to create well-covered vegetation (coverage 87-99\%) as early as next year after sowing in conditions without irrigation. In the next period, the differences in turf coverage between varieties were minimized. The total height of turf and average daily gain of height were the highest in F. arundinacea Schreb. varieties throughout the observed period with significant differences in year 2008 ( $p=0.0239), 2009(p=0.0462)$ and $2011(p=0.0036)$. The most intensive growth had F. arundinacea Schreb. cv. Koreta (1.81 to $3.44 \mathrm{~mm} . \mathrm{d}^{-1}$; i.e. very low to moderate intensity of growth). From point of view of aboveground phytomass production almost throughout the period were used varieties characterized by very low production of phytomass. Among years and varieties were observed differences in the ability thicken vegetation expressed as the ratio of the average daily gain of weight and average daily gain of height (W/H). F. rubra L. cv. Laroma (0.38 to 1.26 g.m $\left.\mathrm{m}^{-2} \cdot \mathrm{mm}^{-1}\right)$ and F. ovina L. cv. Grasina (0.37 to 1.54 g.m-2. $\mathrm{mm}^{-1}$ ) dominated in this indicator except for 2009, when higher values reached F. arundinacea Schreb. cv. Koreta and Levona (both 0.43 g.m $\mathrm{m}^{-2} \cdot \mathrm{mm}^{-1}$; F. rubra L. and F. ovina L. -0.27 and 0.39 g. $\mathrm{m}^{-2} . \mathrm{mm}^{-1}$, respectively).
\end{abstract}

botanical composition, quality, fescues, growth-production process

Turfs, as inevitable and important part of the greenery in the human environment, are characterized by relatively low quality in most cases. Turfgrass quality is not a measure of yield or nutritive value, but it is a measure of aesthetics (i.e. density, uniformity, texture, smoothness, growth habit and colour) and functional use (www.ntep.org/ reports/ratings.htm). GREGOROVÁ, ĎURKOVÁ, TOMAŠKIN (2009) see the reason of inappropriate state of the turfs at the wrong species composition of turfgrass mixtures. Ongoing climatic changes accompanied by the uneven distribution of rainfall and relatively high temperatures, leading to a new perspective on traditional mixtures. As a perspective become species resistant to drought, such as species of the genus Festuca - F. ovina L.,
F. rubra L. and F. arundinacea Schreb. (ČERNOCH, 2001). Warm-season grasses (Zoysia japonica L., Cynodon dactylon (L.) Pers.) are applied in growing of turfs in conditions without irrigation (NAŠINEC, 1999; GREGOROVÁ, ŠMAJSTRLA, 2009). For enhance the quality of turf we can use also slowly growing species such as Koeleria macrantha (Ledeb.) Schult., Poa compressa L., Phleum bulbosum Host non Gouan nom. illeg. or Deschampsia caespitosa (L.) P. Beauv. (MARTINEK et al., 2011). According to NAŠINEC (2006) and HRABĚ et al. (2009) is expected to be wider application of Festuca arundinacea Schreb. turf varieties in common ornamental turfs, as can be seen in southern European countries and the Americas. This not only contributes durability whilst making relatively nice turf (ŠMAJSTRLA, 
2009), but also relatively stable pigment system and deep root system (KOVÁR, 2009). These features remain Festuca arundinacea's turf more green and lush in comparison with drought-resistant Festuca rubra L., which in unfavourable temperature and moisture period passes quickly into summer dormancy with a concomitant reducing the aesthetic quality and functionality of the turf. This was confirmed in experiments of several authors (SCHEFFER, DUNN, MINNER, 1987; HUANG, GAO, 1999; GREGOROVÁ, ĎURKOVÁ, KOVÁR, 2008).

From an economic point of view is also important the intensity of growth and production of aboveground phytomass, especially when growing in low input conditions. Therefore, it is need to know not only biological properties, but also response to environmental conditions and level of caespestechnique in the selection of the species and varieties of turfgrasses (GREGOROVÁ, KOVÁR, 2011).

The aim of this study was to evaluate the quality of turfs of selected Slovak varieties of the genus Festuca under conditions without irrigation.

\section{MATERIAL AND METHODS}

Small-plot experiment with varieties of turf grasses was established in September 2005 in the Experimental and demonstration base of the Department of grassland ecosystems and forage crops in Nitra. Locality is characterized by an annual amount of precipitation at $561 \mathrm{~mm}$, during growing season at $327 \mathrm{~mm}$. The average annual temperature is $9.7^{\circ} \mathrm{C}$, for vegetation $16.5^{\circ} \mathrm{C}$. The average monthly temperatures and precipitation during the growing season of assessed years is shown in Tab. I.

The soil is clay-loam fluvial soils with fluctuating level of subterranean water. Chemical composition of the experimental soil habitat is presented in Tab. II.

We observed follows Slovak varieties of species of the genus Festuca:

- Festuca rubra L. cv. Laroma,

- Festuca ovina L. cv. Grasina,

- Festuca arundinacea Schreb. cv. Levona and cv. Koreta.

All turfs were based by hand sowing 30000 seeds. $\mathrm{m}^{-2}$. Experimental plot size was $1.5 \times 1 \mathrm{~m}$ in 2 replications. Experimental area was irrigated only during the stage of emerging, in the next time were dependent only on atmospheric rainfall.

Before sowing was applied "Starter" fertilizer (N-P-K 17-24-8) in a dose 25 g.m ${ }^{-2}$. In the next years were turfs fertilized by Travcerit (N-P-K 15-3-8) at a dose of $3 \times 10$ g.m $\mathrm{m}^{-2}$ with application in spring, early summer and early autumn.

I: Average monthly temperatures $\left({ }^{\circ} \mathrm{C}\right)$ and sum of precipitation ( $\mathrm{mm}$ ) in years 2005-2011 and their average value for years 1961-1990

\begin{tabular}{|c|c|c|c|c|c|c|c|c|}
\hline Year / month & III & IV & $\mathbf{V}$ & VI & VII & VIII & IX & $\mathbf{X}$ \\
\hline \multicolumn{9}{|c|}{ Temperature ( $\left.{ }^{\circ} \mathbf{C}\right)$} \\
\hline 2005 & 2.7 & 11.0 & 15.2 & 18.0 & 20.7 & 19.1 & 16.3 & 10.7 \\
\hline 2006 & 3.5 & 11.4 & 14.0 & 19.2 & 22.6 & 16.7 & 16.6 & 12.2 \\
\hline 2007 & 7.5 & 12.2 & 16.6 & 21.1 & 22.3 & 21.2 & 13.7 & 9.9 \\
\hline 2008 & 5.5 & 11.1 & 16.0 & 20.0 & 20.4 & 20.5 & 15.4 & 11.2 \\
\hline 2009 & 5.6 & 14.6 & 16.1 & 18.8 & 22.3 & 20.5 & 14.6 & 9.9 \\
\hline 2010 & 5.3 & 10.6 & 15.1 & 20.1 & 23.0 & 19.5 & 14.0 & 7.8 \\
\hline 2011 & 5.9 & 12.7 & 15.8 & 19.8 & 19.7 & 20.9 & 17.7 & 9.9 \\
\hline$\varnothing$ for $1961-1990$ & 5.0 & 10.4 & 15.1 & 18.0 & 19.8 & 19.3 & 15.6 & 10.4 \\
\hline \multicolumn{9}{|c|}{ Precipitation (mm) } \\
\hline 2005 & 3.0 & 79.0 & 61.0 & 32.0 & 59.0 & 95.0 & 47.0 & 12.0 \\
\hline 2006 & 35.2 & 48.1 & 95.6 & 63.9 & 23.7 & 84.0 & 12.7 & 15.3 \\
\hline 2007 & 58.0 & 0 & 106.7 & 36.0 & 35.6 & 78.9 & 91.2 & 31.6 \\
\hline 2008 & 62.7 & 36.4 & 55.4 & 86.2 & 90.0 & 9.8 & 51.5 & 30.2 \\
\hline 2009 & 52.0 & 20.0 & 37.9 & 81.1 & 94.1 & 26.1 & 47.2 & 27.0 \\
\hline 2010 & 20.6 & 95.3 & 157.1 & 158.3 & 51.9 & 103.3 & 76.7 & 28.7 \\
\hline 2011 & 0.2 & 13.2 & 48.4 & 91.1 & 121.6 & 152.3 & 92.1 & 36.7 \\
\hline$\varnothing$ for 1961-1990 & 30.0 & 39.0 & 58.0 & 66.0 & 52.0 & 61.0 & 40.0 & 36.0 \\
\hline
\end{tabular}

Source: Meteorological station Nitra

II: Chemical soil properties of the experimental stand

\begin{tabular}{|c|c|c|c|c|c|c|c|}
\hline$N_{t}$ & $\mathbf{P}$ & $\mathbf{K}$ & $\mathrm{Mg}$ & $\mathrm{Ca}$ & $\mathrm{Na}$ & $\mathrm{C}_{\mathrm{ox}}$ & $\mathrm{pH} / \mathrm{KCl}$ \\
\hline & \multicolumn{4}{|c|}{ mg.kg-1 } & \multicolumn{3}{|c|}{$\%$} \\
\hline 2282 & 54 & 350 & 680 & 4900 & 40 & 2,082 & 7,09 \\
\hline
\end{tabular}


Turfs were regularly mowed to a height of $50 \mathrm{~mm}$ at an average height of 80-100 mm. In May 2009 was realised verticutation and in August of the same year herbicide treatment (Aminex ${ }^{\circledast} 500$ SL).

In paper we present the development of turf botanical composition in \% dominance, average daily gain of height $\left(\mathrm{mm}^{-1} \mathrm{~d}^{-1}\right)$ which was calculated as difference of turf height between $n$ and $n-1$ cut divided by number of days between $n$ and $n-1$ cut and average daily gain of weight $\left(\mathrm{g} \cdot \mathrm{d}^{-1} \cdot \mathrm{m}^{-2}\right)$ which was calculated as difference of aboveground phytomass weight between $n$ and $n-1$ cut divided by number of days between $n$ and $n-1$ cut, yearly vegetation height (mm) and yearly yield of dry aboveground phytomass $\left(\mathrm{g} \cdot \mathrm{m}^{-2}\right)$ and the average daily gain of dry aboveground phytomass weight / average daily gain of height ratio $\left(\mathrm{g} \cdot \mathrm{m}^{-2} \cdot \mathrm{mm}^{-1}\right)$. Obtained values were compared with the classifier of the family Poaceae (ŠEVČÍKOVÁ, ŠRÁMEK, FABEROVÁ, 2002).

The statistical analysis was carried out using Statistica vers. 7.1 Statsoft, Inc. (2005). Differences between treatments were analyzed by one way ANOVA with multiple comparisons according to Fischer $(\mathrm{p}<0.05)$. Figures were created by MS Excel.

\section{RESULTS AND DISCUSSION}

The development of botanical composition of evaluated Slovak varieties of Festuca in the years 2005-2011 is presented in Tab. III.

Initially, all experimental plots were characterized by a high proportion of blank places (32-55\%) and relatively high weed infestation (3-20\%), especially species such as Convolvulus arvensis L. and Taraxacum officinale (L.) Weber. Regular mowing and gradual expansion of grasses decreased proportion of blank places to the end of 2006 to $1-13 \%$. Also been reported a reduction of weeds to a minimum (less than $1 \%)$. In the next period, all evaluated varieties of Festuca had high cover (92-99\%). The only exceptions were Festuca arundinacea Schreb. varieties Koreta and Levona which cover in autumn 2007 were $89 \%$ and $88 \%$, respectively. We can say, that in the $3^{\text {rd }}(2007)$ and $4^{\text {th }}$ year $(2008)$ were more covered turfs of Festuca rubra L. cv. Laroma and Festuca ovina L. cv. Grasina in comparison with Festuca arundinacea Schreb. varieties. These differences are minimized transition into the next growing season (year 2009). All the turfs were considerably thinned after verticutation at the beginning of May 2009. Due to the growing turfs in conditions without irrigation, the resilience of the species was low and the created blank places were filled by weeds. A selective herbicide was used for the removal of weeds in August 2009. The most significant turf damage was reported at Festuca rubra L. cv. Laroma (47 \% cover of grass component). At least damaged were Festuca arundinacea Schreb. cv. Koreta and cv. Levona turfs, where presence of the grass component was at 99 \% for both varieties (period autumn 2009). The following period was characterized by a gradual recovery of vegetation, which is reflected in the increasing coverage of grasses, most significant in the Festuca ovina L. and Festuca arundinacea Schreb. At the end of the growing season 2010, the cover of all vegetation was relatively high (90-95 \%). In 2011, turfs of Festuca arundinacea Schreb. had the best ground cover (Koreta - 97-99 \%; Levona - 98$100 \%$ ). Then follow Festuca rubra L. cv. Laroma with 94-96\% and finally Festuca ovina L. cv. Grasina with 93-95 \% coverage. In the last two growing seasons was also observed transient slight increase in the presence of weeds. Festuca ovina L. cv. Grasina had the most $(7 \%)$ weeds at the end of the reporting period (autumn 2011). On the base of the obtained results it can be concluded that the varieties of fescues create a well-covered turfs in conditions without irrigation. They also showed their good resilience of damage, especially in Festuca arundinacea Schreb. This confirmed ŠEVČÎ́KOVÁ and ŠRÁMEK

III: Botanical composition (\%) of evaluated turfgrass varieties during 2005-2011

\begin{tabular}{|c|c|c|c|c|c|c|c|c|c|c|c|c|c|c|}
\hline $\begin{array}{c}\text { Species/ } \\
\text { variety }\end{array}$ & Group & $\frac{2005}{A}$ & \multicolumn{2}{|c|}{2006} & \multicolumn{2}{|c|}{2007} & \multicolumn{2}{|c|}{2008} & \multicolumn{2}{|c|}{2009} & \multicolumn{2}{|c|}{2010} & \multicolumn{2}{|c|}{2011} \\
\hline \multirow{3}{*}{$\begin{array}{l}\text { Festuca } \\
\text { rubra } \\
\text { cv. Laroma }\end{array}$} & BP & 34 & 40 & 8 & 4 & 1 & 1 & 4 & 2 & 53 & 22 & 7 & 4 & 2 \\
\hline & G & 60 & 40 & 92 & 96 & 95 & 98 & 92 & 98 & 47 & 76 & 90 & 94 & 96 \\
\hline & $\mathbf{W}$ & 6 & 20 & + & 0 & 4 & 1 & 4 & 0 & 1 & 2 & 3 & 2 & 2 \\
\hline \multirow{2}{*}{$\begin{array}{l}\text { Festuca } \\
\text { ovina } \\
\text { cv. Grasina }\end{array}$} & G & 47 & 62 & 99 & 99 & 96 & 99 & 94 & 97 & 90 & 94 & 94 & 95 & 93 \\
\hline & $\mathbf{W}$ & 5 & 3 & 0 & + & 3 & 1 & 5 & 3 & 2 & 2 & 5 & 5 & 7 \\
\hline \multirow{2}{*}{$\begin{array}{l}\text { Festuca } \\
\text { arundinacea } \\
\text { cv. Koreta }\end{array}$} & BP & 32 & 50 & 3 & 4 & 1 & 3 & 0 & 1 & 1 & 9 & + & 0 & 0 \\
\hline & G & 65 & 45 & 97 & 96 & 89 & 93 & 97 & 97 & 99 & 89 & 95 & 97 & 99 \\
\hline \multirow{2}{*}{$\begin{array}{l}\text { Festuca } \\
\text { arundinacea } \\
\text { cv. Levona }\end{array}$} & G & 50 & 40 & 87 & 92 & 88 & 94 & 96 & 96 & 99 & 85 & 94 & 98 & 100 \\
\hline & $\mathbf{W}$ & 10 & 5 & + & 1 & 9 & 2 & 3 & 2 & + & 1 & 5 & 2 & + \\
\hline
\end{tabular}

A - autumn; $\mathrm{S}$ - spring; $\mathrm{BP}=$ blank places; $\mathrm{G}=$ grasses; $\mathrm{W}=$ weeds; + = less than $1 \%$ 
(1998) by the results of experiment, from which result the highest resistance of Festuca arundinacea Schreb. to mechanical stress (reduction of coverage grass component by only $17 \%$ in comparison with other species, as measured).

Due to the lack of ground cover at the beginning of the growing season in 2006, in next text we evaluate the growth-production process of selected varieties for the years 2007-2011. The total height of turf for growing season (Fig. 1) and average daily gains in height (Tab. IV) were the highest in Festuca arundinacea Schreb. varieties during the whole period with significant differences in year 2008 ( $p=0.0239), 2009(p=0.0462)$ and $2011(p=0.0036)$. The most intense growth showed Festuca arundinacea

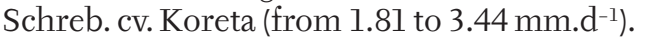

According to classifier for grass (ŠEVČÍKOVÁ, ŠRÁMEK, FABEROVÁ, 2002), it can be assigned 9-5 points on a scale of $1-9$, where 9 is the best rating level of the evaluated characteristic. Conversely, the slowest growth was characterized by Festuca ovina L. cv. Grasina and its total height for the growing season was significantly different $(p=0.0053)$ from $177.0 \mathrm{~mm}$ (2009) to $376.5 \mathrm{~mm}$ (2007). These values correspond to the average daily gain of height (0.93 mm.d $\mathrm{d}^{-1}-2009$; 1.84 mm. $\left.\mathrm{d}^{-1}-2007\right)$. According to the classifier it can classify 9 points, i.e. very low intensity of growth. Turfgrass varieties should create a dense, well-covered, colour and aesthetic acting turf with stable sod, suitable mechanical properties of roots and leaves (FIALA, 1992; TICHÝ, 1992). Therefore, the less values of height gain are positive evaluated. This knowledge is important for the formation of mixtures of representation ornamental turfs where grass with different growth rhythm disturb aesthetics of turf (GREGOROVÁ, 2001).

Equally important indicator of the turf quality is a yearly production of aboveground phytomass (Fig. 2) and the intensity of phytomass growth expressed as average daily gain of phytomass

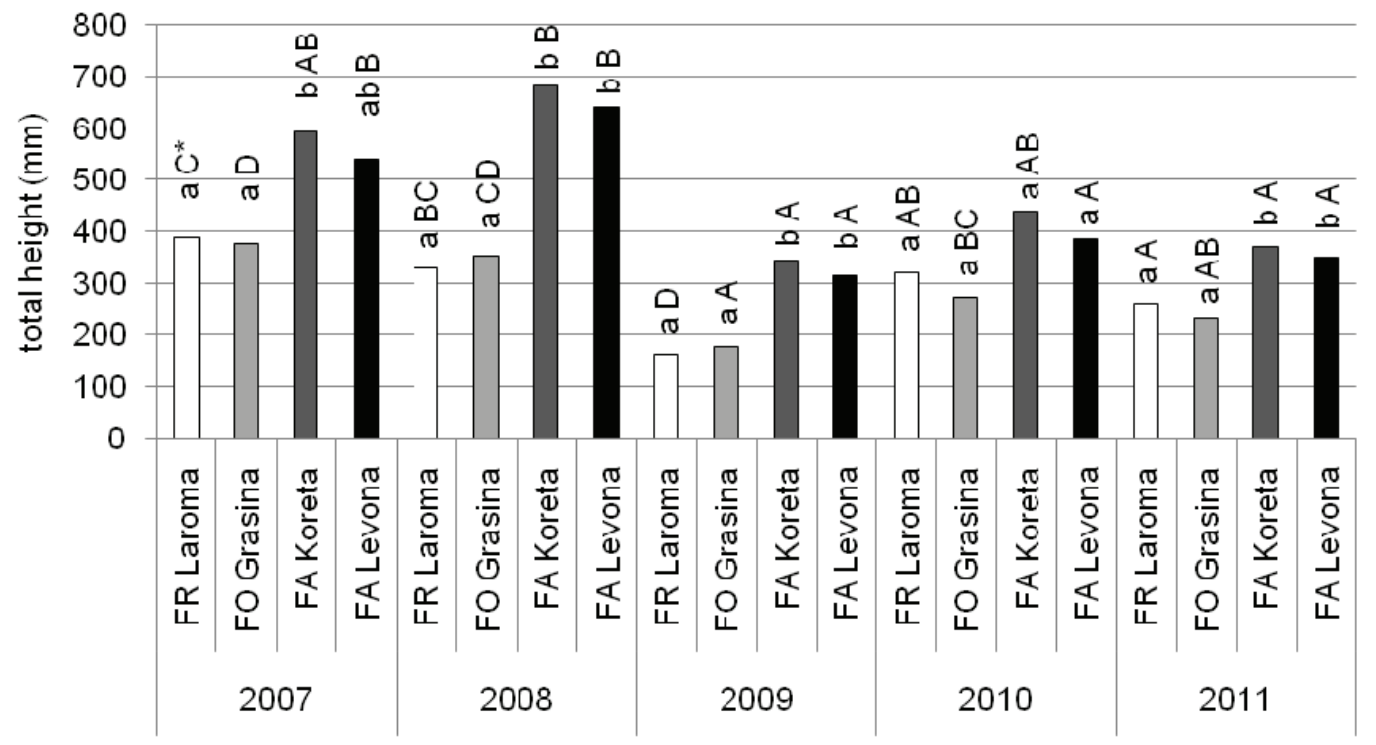

1: Total height (mm) of turf for growing season

FR - Festuca rubra; FO - Festuca ovina; FA - Festuca arundinacea

$*$ Different letters ( $a-d$ for species/variety and $\boldsymbol{A}-\mathbf{D}$ for years) indicate significant differences at $\mathrm{p}<0.05$ level.

IV: Average daily gain of height for the growing season with points allocated according to the classifier of the Poaceae (Ševč́ková, Šrámek and Faberová, 2002)

\begin{tabular}{|c|c|c|c|c|c|c|c|c|c|c|}
\hline \multirow{2}{*}{$\begin{array}{c}\text { Species/ } \\
\text { Variety }\end{array}$} & \multicolumn{2}{|c|}{ year 2007} & \multicolumn{2}{|c|}{ year 2008} & \multicolumn{2}{|c|}{ year 2009} & \multicolumn{2}{|c|}{ year 2010} & \multicolumn{2}{|c|}{ year 2011} \\
\hline & mm.d $^{-1}$ & pt & $\mathrm{mm} \mathrm{d}^{-1}$ & pt & $\mathrm{mm} \mathrm{d}^{-1}$ & pt & mm.d $^{-1}$ & pt & $\mathrm{mm} \mathrm{d}^{-1}$ & pt \\
\hline FR Laroma & $\begin{array}{c}1.88 a b \\
A^{*}\end{array}$ & 9 & $\begin{array}{c}1.65 \\
a \boldsymbol{A}\end{array}$ & 9 & $\begin{array}{c}0.85 \\
a \mathbf{B}\end{array}$ & 9 & $\begin{array}{l}1.83 \\
a b \boldsymbol{A}\end{array}$ & 9 & $\begin{array}{l}1.21 \\
a \mathbf{C}\end{array}$ & 9 \\
\hline FO Grasina & $\begin{array}{c}1.84 a \\
\boldsymbol{A}\end{array}$ & 9 & $\begin{array}{l}1.82 \\
a \mathbf{A}\end{array}$ & 9 & $\begin{array}{l}0.93 \\
a b \mathbf{B}\end{array}$ & 9 & $\begin{array}{c}1.56 \\
b \boldsymbol{A}\end{array}$ & 9 & $\begin{array}{l}1.10 \\
a \mathbf{B}\end{array}$ & 9 \\
\hline FA Koreta & $\begin{array}{c}2.89 b \\
\boldsymbol{A B}\end{array}$ & 7 & $\begin{array}{l}3.44 \\
b \text { B }\end{array}$ & 5 & $\begin{array}{l}1.81 \\
c \boldsymbol{A}\end{array}$ & 9 & $\begin{array}{l}2.81 \\
a \mathbf{A B}\end{array}$ & 7 & $\begin{array}{l}1.97 \\
b \boldsymbol{A}\end{array}$ & 9 \\
\hline FA Levona & $\begin{array}{c}2.63 a b \\
\mathbf{A B}\end{array}$ & 7 & $\begin{array}{l}3.23 \\
b \boldsymbol{B} \\
\end{array}$ & 5 & $\begin{array}{l}1.66 \\
b c \mathbf{C}\end{array}$ & 9 & $\begin{array}{l}2.58 \\
a \mathbf{A B} \\
\end{array}$ & 7 & $\begin{array}{l}1.94 \\
b \boldsymbol{A}\end{array}$ & 9 \\
\hline
\end{tabular}

FR - Festuca rubra; FO - Festuca ovina; FA - Festuca arundinacea

pt (points): 9 points = very low intensity of growth; 1 point = very high intensity of growth

$*$ Different letters in each column $(a-d)$ and in each line $(\boldsymbol{A}-\mathbf{D})$ indicate significant differences at $\mathrm{p}<0.05$ level. 


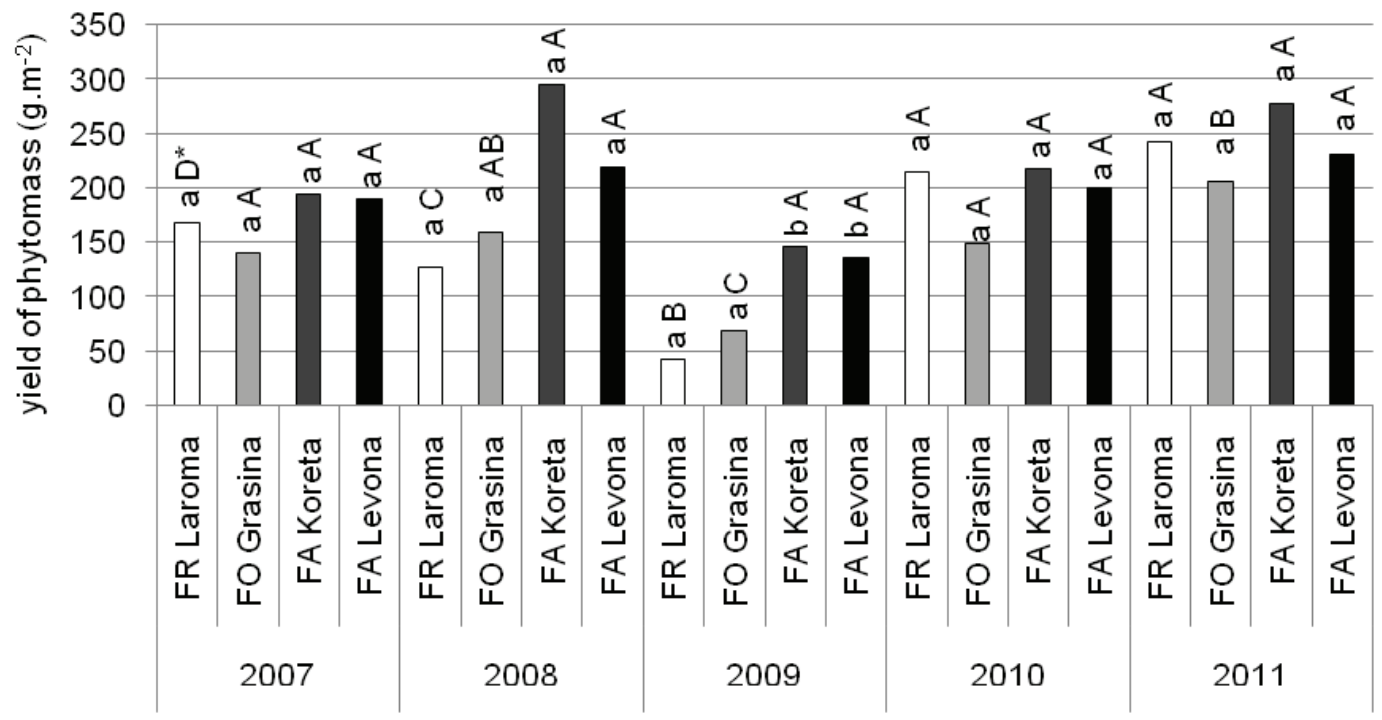

2: Total yield of dry aboveground phytomass (g. $\left.\mathrm{m}^{-2}\right)$

FR - Festuca rubra; FO - Festuca ovina; FA - Festuca arundinacea

$*$ Different letters ( $a-d$ for species/variety and $\boldsymbol{A}-\mathbf{D}$ for years) indicate significant differences at $\mathrm{p}<0.05$ level.

V: Average daily gain of weight of dry aboveground phytomass $\left(g . d^{-1} \cdot m^{-2}\right)$

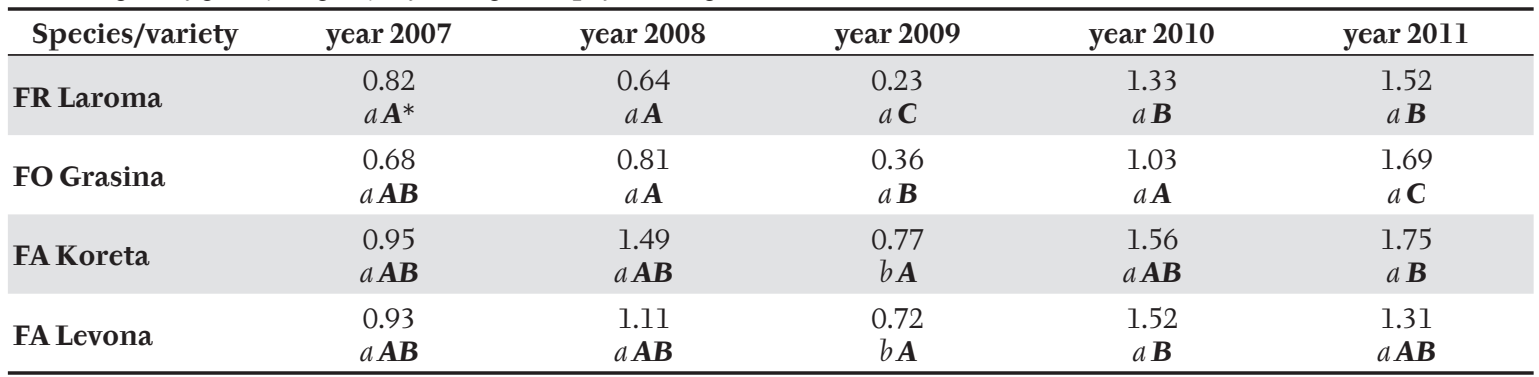

FR - Festuca rubra; FO - Festuca ovina; FA - Festuca arundinacea

$*$ Different letters in each column $(a-d)$ and in each line $(\boldsymbol{A}-\mathbf{D})$ indicate significant differences at $\mathrm{p}<0.05$ level.

(Tab. V). According to the used classifier, all rated Festuca varieties were characterized by very low (up to $250 \mathrm{~g} . \mathrm{m}^{-2}$ ) production of aboveground phytomass, which corresponds to one point on a scale of 1-9, where $l$ is the best rating level of the evaluated characteristic. Festuca arundinacea Schreb. cv. Koreta was the exception, which in year 2008 and 2011 had yearly production of dry aboveground phytomass at 294.9 g.m $\mathrm{m}^{-2}$ and 277.10 g.m $\mathrm{m}^{-2}$ (i.e. 2 points on that scale), respectively. Although the values of aboveground phytomass production was reflected good resilience of Festuca arundinacea Schreb., when its varieties in 2009 (after verticutation) achieved significantly $(p=0.0212)$ higher production of phytomass in comparison with Festuca ovina L. cv. Grasina and Festuca rubra L. cv. Laroma.

In addition to the indicators for evaluating the quality of turfs we can use the ratio between values of the average daily gain of aboveground phytomass and average daily gain of height $(\mathrm{W} / \mathrm{H})$, which is positively correlated $(r=0.82$ ) with turf density (i.e. number of shoots per unit area). The higher $\mathrm{W} / \mathrm{H}$ ratio value corresponds with more phytomass per unit area calculated per unit height of the turf, i.e. turf is denser. The values of this indicator, presented in Tab. VI show that initially was denser Festuca rubra L. cv. Laroma and Festuca ovina L. cv. Grasina turf in comparison with Festuca arundinacea Schreb. varieties. Another growing season was for Festuca arundinacea Schreb. cv. Koreta and cv. Levona characterized by a statistically significant $(p=0.0010$ and $\mathrm{p}=0.0192$, respectively) gradual increase of $\mathrm{W} / \mathrm{H}$ ratio, which is related to the natural thickening of turf. Transitional thinning of turf was recorded at Festuca rubra L. (in 2008 and 2009) and in Festuca ovina L. (in 2009). They regenerate well after mechanical intervention (verticutation) and create denser turfs than Festuca arundinacea Schreb. varieties. It was confirmed the finding of the ability of fine leaved fescues (F. rubra L. and F. ovina L.) to form dense turf (STRAKOVÁ, 2001, HAN, SONG, ZHANG, 2008). 
VI: Average daily gain of weight of dry aboveground phytomass / average daily gain of height ratio for growing season (W/H) (g.m ${ }^{-2}$.mm $\left.{ }^{-1}\right)$

\begin{tabular}{|c|c|c|c|c|c|}
\hline Species/variety & year 2007 & year 2008 & year 2009 & year 2010 & year 2011 \\
\hline FR Laroma & $\begin{array}{l}0.44 \\
a \boldsymbol{A}^{*}\end{array}$ & $\begin{array}{c}0.38 \\
a \boldsymbol{A}\end{array}$ & $\begin{array}{c}0.27 \\
a \mathbf{A}\end{array}$ & $\begin{array}{c}0.73 \\
a \boldsymbol{B}\end{array}$ & $\begin{array}{l}1.26 \\
a b \mathrm{C}\end{array}$ \\
\hline FA Koreta & $\begin{array}{c}0.33 \\
a \mathbf{A}\end{array}$ & $\begin{array}{l}0.43 \\
a \mathbf{A B}\end{array}$ & $\begin{array}{l}0.43 \\
a \boldsymbol{A B}\end{array}$ & $\begin{array}{c}0.55 \\
a \mathbf{B}\end{array}$ & $\begin{array}{c}0.88 \\
a \mathbf{C}\end{array}$ \\
\hline
\end{tabular}

FR - Festuca rubra; FO - Festuca ovina; FA - Festuca arundinacea

*Different letters in each column $(a-d)$ and in each line $(\boldsymbol{A}-\mathbf{D})$ indicate significant differences at $\mathrm{p}<0.05$ level.

\section{SUMMARY}

The development of botanical composition in the period 2005-2011 and the growth- production process in the years 2007-2011 were evaluated in small-plots field experiment with selected Slovak varieties of species of the genus Festuca. Experiment was realized in conditions without irrigation of south-western Slovakia (locality Nitra). Based on the data it can be concluded that the varieties of fescue created well-covered turfs in conditions without irrigation. It also can be evaluated positively their good resilience of damage, especially for Festuca arundinacea varieties. It achieved significantly $(\mathrm{p}=0.0212)$ higher production of phytomass than Festuca ovina L. cv. Grasina and Festuca rubra L. cv. Laroma after verticutation. The evaluation of the growth-production process of selected varieties showed that they are well-suitable to moderately suitable for turf use.

\section{REFERENCES}

A guide to NTEP Turfgrass Ratings, 2012: [cit. 201202-17]. Cited from http://www.ntep.org/reports/ ratings.htm.

ČERNOCH, V., 2001: Vliv zložení trávníkových směsí na kvalitu trávníků. Trávníky 2001 (ročenka českého trávníkářství). Hrdějovice: Agentura BONUS 2001: 26-28, ISBN 80-902690-3-6.

FIALA, J., 1992: Trávníky jsou významnou součastí životního prostředí. Trávníky-sport-zeleň-ekologie (odborný štvrtročník), 2, 2: 29-31.

GREGOROVÁ, H., 200l: Trávnikárstvo. Nitra: SPU Ochrana biodiverzity 312001, 108 s. ISBN 807137-876-3.

GREGOROVÁ, H., ĎURKOVÁ, E., KOVÁR, P., 2008: Dynamika rastu vybraných trávnikových odrôd druhov rodu Festuca v podmienkach deficitu vlahy a nízkych vstupov. In: Aktuálne problémy riešené $v$ agrokomplexe [CD-ROM]. Nitra: SPU, 2008: 5-9. ISBN 978-80-552-0151-1.

GREGOROVÁ, H., ĎURKOVÁ, E., TOMAŠKIN, J., 2009: Floristické zloženie okrasných trávnikov vo vybraných mestách Slovenska. Trávniky v 21. storočí (zborník zo seminára) Nitra: SPU 2009, s. 61-66. ISBN 978-80-552-0290-7.

GREGOROVÁ, H., KOVÁR, P., 201l: The evaluation of selected qualitative indicators of Festuca species varieties under the conditions of moisture deficit. In: SUPUKA, J. and BIHUŇOVÁ, M. (ed.) Settlement-park-landscape: revitalisation of green urban open spaces with consideration to changing environment. V. Nitra: Slovak University of Agriculture, 2011, pp. 364-374. ISBN 978-80-552-0540-3.
GREGOROVÁ, H., ŠMAJSTRLA, V., 2009: Trávniky V 21. storočí. Trávniky v 21. storoči (zb. zo seminára) Nitra: SPU 2009, s. 5-9. ISBN 978-80-552-0290-7.

HAN, L.-B., SONG, G.-L., ZHANG, X., 2008: Preliminary observations on physiological responses of three turfgrass species to traffic stress. Horttechnology, 18, 1: 139-143

HRABĚ, F., CAGAŠ, B., ČERNOCH, V., DEKAŘ, J., GRÉZL, V., HEJDUK, S., CHYTKA, T., KNOT, P., KUŤKOVÁ, T., MÜLLER-BECK, K., NAŠINEC, I., POSPÍCHALOVÁ, H., SKLÁDANKA, J., STRAKA, J., STRAKOVÁ, M., ŠEVČÍKOVÁ, M., VIKTORÍN, J., VORLÍČEK, Z., ZEMKOVÁ, L., ZIITKO, J., 2009: Trávníky pro zahradu, krajinu a sport. Olomouc: Vydavatelství Ing. Petr Baštan, 2009, 335 s. ISBN 978-80-87091-07-4.

HUANG, B. and GAO, H., 1999: Physiological responses of diverse tall fescue cultivars to drought stress. HortScience, 34: 897-901.

KOVÁR, P., 2009: Floristické zloženie a kvalita trávnikových porastov $v$ podmienkach low input caespestechniky. (Dizertačná práca) Nitra: SPU 2009, $138 \mathrm{~s}$.

MARTINEK, J., SVOBODOVÁ, M., KRÁLÍČKOVÁ, T., NAŠINEC, I., 2011: Evaluation of Deschampsia caespitosa (L.) Beauv. competition ability in mixtures with main turfgrass species. Acta univ. agric. et silvic. Mendel. Brun., 51, 5: 159-168. ISSN 1211-8516.

NAŠINEC, I., 1999: Odolnost trav vůči suchu a zastínení. Trávníky 99. Hrdějovice: Agentura BONUS 1999, s. 21. ISBN 80-902690-3-6.

NAŠINEC, I., 2006: Současné směry šlechtění trav a sestavování trávních směsí. Trávníky 2006. 
Hrdějovice: Agentura BONUS 2006, s. 21-23. ISBN 80-86802-06-X.

SCHEFFER, K. M., DUNN, J. H., MINNER, D. D., 1987: Summer drought responses and rooting depth of three cool-season turfgrasses. HortScience, 22: 296-297.

ŠEVČÍKOVÁ, M., ŠRÁMEK, P., 1998: Hodnocení reakce travního drnu na mechanické zatěžování v polní kolekci genetických zdrojů trávnikových odrůd trav. Trávníky 1998, Hrdějovice: Agentura BONUS, 1998, s. 27-29. ISBN 80-902454-2-0.
ŠEVČÍKOVÁ, M., ŠRÁMEK, P. and FABEROVÁ, I., 2002: Klasifikátor-Trávy.Zubří: OSEVA PRO, s.r. o., 2002, s. 34.

ŠMAJSTRLA, V., 2009: Aktuálne otázky caespestechniky. Trávniky v 21. storoči (zborník zo seminára) Nitra: SPU 2009, s. 36-39. ISBN 978-80552-0290-7.

STRAKOVÁ, M., 2001: Vývoj a struktura nadzemní a podzemní biomasy trávníkových odrid trav: Dizertačná práca. Brno: MZLU, 2001, s. 120.

TICHÝ, V., 1992: Vlastnosti některých pícních trav použitelných pro trávníky. Trávníky-sport-zeleñekologie (odborný štvrtročník), 2, 2:33-34.

Address

Ing. Peter Kovár, PhD., Ing. L'uboš Vozár, PhD., prof. Ing. Ján Jančovič, PhD., Katedra trávnych ekosystémov a kŕmnych plodín, Fakulta agrobiológie a potravinových zdrojov, Slovenská polnohospodárska univerzita v Nitre, Tr. A. Hlinku 2, 94976 Nitra, Slovenská republika, e-mail: Peter.Kovar@uniag.sk 
